\begin{tabular}{cc}
\hline Jurnal Pendidikan Biologi 8 (1) (2018) $14-19$ \\
Jurnal Pendidikan Biologi \\
2
\end{tabular}

\title{
Aplikasi Lesson Study dalam Meningkatkan Kompetensi Profesional Guru di Madrasah Aliyah Bustanul Ulum Kota Langsa
}

\author{
Nursamsu, Allif Syahputra Bania \& Elfrida \\ Program Studi Pendidikan Biologi Fakultas Keguruan dan Ilmu Pendidikan, Universitas Samudra Langsa, \\ Meurandeh, Langsa 24416, Aceh, Indonesia
}

\section{INFO ARTIKEL}

Histori Artikel

Received 10 Oktober 2018

Revised 4 Desember 2018

Accepted 10 Desember 2018

Published 12 Desember 2018

Keywords:

Competence,

Lesson study,

Profesional

\begin{abstract}
The purpose of the study was to describe the lesson study learning process. The application of lesson study is in the form of a cycle of planning, implementation, and reflection. This research method is research in the form of class action (action research) which consists of two cycles. Data retrieval is done by observation sheet to the model teacher in carrying out biology learning activities, interviews and questionnaires. Furthermore, the data analysis technique in the complete study uses three simultaneous activities, namely; (1) data reduction; (2) data presentation and (3) inference and verification of data. The results of this study consisted of two cycles: (1) Cycle I of the application of lesson study learning stages was categorized good with a value of $81.66 \%$; (2) Cycle II is the advanced stage of the results of weaknesses and shortcomings in the first cycle, at this stage the lesson study learning application is categorized good with a value of $89.58 \%$. Then it can be concluded that the lesson study learning application can improve teacher professional competence, and make the learning atmosphere active and creative, so students are enthusiastic to learn.
\end{abstract}

Copyright (C) 2018 Universitas Negeri Medan. Artikel Open Access dibawah lisensi CC-BY-4.0 (https://creativecommons.org/licenses/by/4.0)

\section{How to Cite}

Nursamsu, Bania, A. S., \& Elfrida (2018) Aplikasi Lesson Study dalam Meningkatkan Kompetensi Profesional Guru di Madrasah Aliyah Bustanul Ulum Kota Langsa. Jurnal Pendidikan Biologi, 8(1), 14-19.

\section{PENDAHULUAN}

Guru pada dasarnya merupakan seorang pendidik untuk mencerdaskan anak bangsa, maka dari itulah guru wajib mempunyai kompetensi profesional untuk kegiatan pembelajaran. Sebab itulah profesional guru dalam menjalani tugas pokoknya sebagai pengajar adalah mendidik, mengajar, membimbing, melatih, mengarahkan, menilai, dan mengevaluasi (Undang-undang Guru dan
Dosen Republik Indonesia Nomor 14 Tahun 2005).

Profesional guru dalam melaksanakan kegiatan pembelajaran, maka guru dituntut untuk melaksanakannya dengan menggunakan berbagai macam model, metode dan strategi untuk menyampaikan materi tentang pembelajaran. Dalam peningkatan profesionalan guru dalam proses kegiatan pembelajaran, dengan cara mengimplementasikan Lesson study. Menurut Subanji \& 
Isnandar (2010) menyatakan dengan adanya Lesson Study, guru dapat mengkolaborasikan ide yang ada untuk menciptakan suatu pembelajaran yang menarik dan inovatif.

Menurut White \& Lim (2008) lesson study merupakan sebuah kegiatan di mana guru dapat mengembangkan proses pengembangan pembelajaran dan keterampilan profesional dalam meningkatkan hasil pembelajaran siswa. Sedangkan menurut Susilo (2011) lesson study adalah suatu kegiatan pembelajaran yang dilaksanakan oleh guru untuk meningkatkan kualitas pembelajaran dan pengembangan keprofesionalan guru.

Proses kegiatan pembelajaran sebagai guru model lesson study, ada beberapa tahap menurut Lewis (2002) mendiskripsikan proses tersebut sebagai langkah-langkah kolaborasi dengan guru-guru untuk merencanakan (plan), mengamati (observe), dan melakukan refleksi (reflect) terhadap pembelajaran (lesson). Tahapan lesson study tersebut yang menjadi dasar dapat meningkatan profesional guru sebagai guru model untuk menyampaikan materi kepada siswa.

Berdasarkan berbagai penjelasan tentang alasan diatas, maka perlu pembelajaran dengan menggunakan lesson study, antar guru dan siswa. Tujuan dari penelitian adalah untuk mendekripsikan proses pembelajaran lesson study. Aplikasi lesson study berupa siklus tahapan merencanakan (plan), pelaksanaan (do) dan refleksi (see).

\section{METODE}

Metode penelitian ini adalah peneltian berupa tindakan kelas (Action Reseach) yang terdiri dari dua siklus. Tahapan siklus yang akan dilaksanakan pada pembelajaran lesson study terdiri dari perencanaan (plan), pelaksanaan (do) dan refleksi (see). Adapun tahapan rancangan pembelajaran lesson study dalam penelitian terlihat pada gambar dibawah ini.

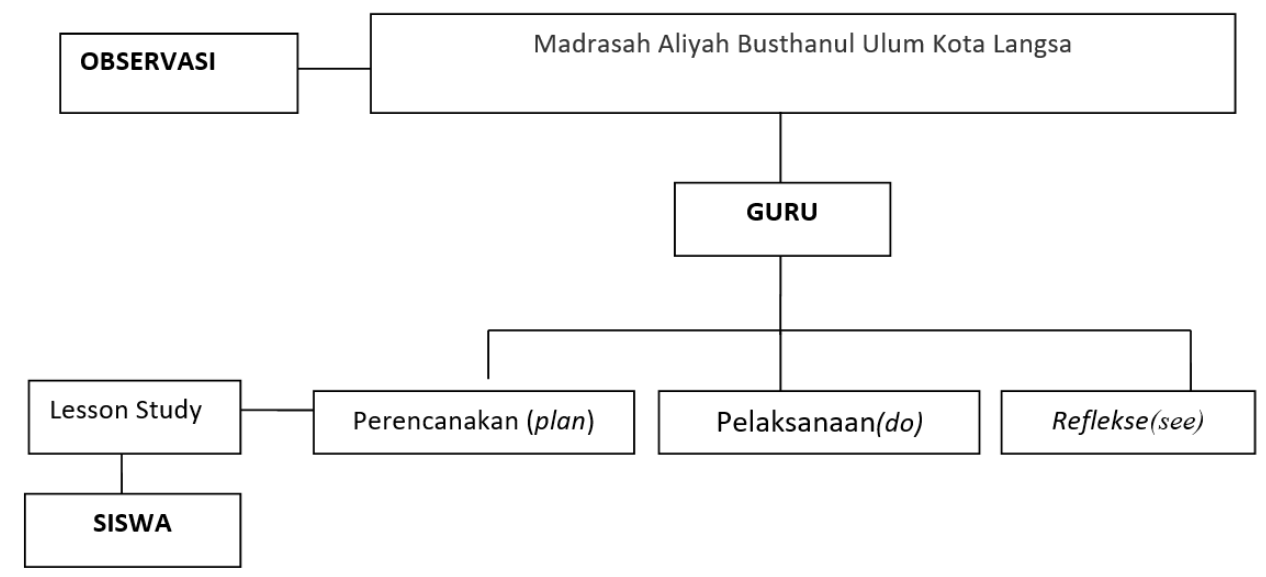

Gambar 1. Tahap Penelitian Lesson Study

Pelaksanaan penelitian ini di Madrasah Aliyah Busthanul Ulum Kota Langsa pada bulan Juli 2018 yang terdiri 3 orang guru sebagai sampel penelitian. Pengambilan data dilakukan dengan lembar observasi kepada guru model dalam melaksanakan kegiatan pembelajaran biologi, wawancara dan angket. Selanjutnya teknik analisis data dalam penelitian secara lengkap menggunakan tiga alur kegiatan secara bersamaan yaitu; (1) reduksi data; (2) penyajian Data dan (3) penyimpulan dan verifikasi data. 


\section{HASIL DAN PEMBAHASAN}

Pelaksanaan pembelajaran lesson study yang akan dilaksanakan oleh tim peneliti untuk diterapkan oleh guru model di Madrasah Aliyah Busthanul Ulum Kota Langsa, yang terdiri dari dua siklus sebagai berikut.

\section{Siklus I}

Pada tahap siklus I dimana tim penelitian sebagai observer. Pada tahap ini tim melihat proses pembelajaran lesson study oleh guru model. Siklus I guru model melaksanakan pembelajaran lesson study dengan tahapan perencanaan (plan), dimana tahap ini mempersiapkan prangkat pembelajaran seperti silabus, RPP, model dan media pembelajaran yang akan disajikan untuk kegiatan pembelajaran lesson study. Tahap pelaksanaan (do) dimana tim penelitian sebagai observer akan monitoring guru model yang melaksanaan kegiatan pelaksanaan $(d o)$. Pada tahap ini guru model melaksanakan kegiatan lesson study menggunakan berbagai macam model dan media pembelajaran, guru model melaksanakan pembelajaran kepada siswa belajar secara kelompok. Sedangkan Tahap refleksi (see) merupakan tahap penilaian terakhir yang yang dilaksanakan observer pada guru model. Pada tahap ini guru model dinilai kelebihan dan kekurangan dalam penyampaian dari hasil kegiatan pembelajaran berlangsung dengan mengimplementasikan tahapan refleksi (see). Adapun hasil yang diperoleh dalam tahap siklus I yang didapat oleh guru model terdapat pada Tabel 1.

Tabel 1. Hasil Penelitian Siklus I Pelaksanaan Lesson Study

\begin{tabular}{|c|c|c|c|c|c|c|}
\hline No & Indikator & GM1 & GM2 & GM3 & $\%$ & Kriteria \\
\hline 1. & Perlengkapan perangkat pembelajaran & 3 & 2 & 3 & 66,66 & Cukup \\
\hline 2. & $\begin{array}{l}\text { Kemampuan apersepsi yang akan dilaksanakan pada saat } \\
\text { membuka pelajaran }\end{array}$ & 3 & 3 & 3 & 75,00 & Baik \\
\hline 3. & Kejelasan dalam penyampaian materi & 3 & 4 & 3 & 83,33 & Baik \\
\hline 4. & $\begin{array}{l}\text { Guru model memanfaatkan model dan media } \\
\text { pembelajaran sesuai dengan perangkat pembelajaran yang } \\
\text { disebutkan dalam RPP }\end{array}$ & 3 & 4 & 3 & 83,33 & Baik \\
\hline 5. & $\begin{array}{l}\text { Guru model melaksanakan pembelajaran kepada siswa } \\
\text { belajar secara berkelompok }\end{array}$ & 3 & 3 & 3 & 75,00 & Baik \\
\hline 6. & Melakukan evaluasi pembelajaran & 3 & 3 & 3 & 75,00 & Baik \\
\hline 7. & $\begin{array}{l}\text { Melaksanakan pembelajaran dengan umpak balik dan } \\
\text { pujian }\end{array}$ & 3 & 3 & 3 & 75,00 & Baik \\
\hline 8. & Menyimpulkan materi pelajaran & 3 & 3 & 3 & 75,00 & Baik \\
\hline 9. & Kemampuan untuk menutup pembelajaran & 3 & 3 & 3 & 75,00 & Baik \\
\hline 10. & $\begin{array}{l}\text { Penggunaan waktu sesuai dengan rencana alokasi waktu } \\
\text { dalam RPP }\end{array}$ & 3 & 2 & 3 & 66,66 & Cukup \\
\hline 11. & $\begin{array}{l}\text { Guru model yang mengajar dapat menerima saran } \\
\text { perbaikan }\end{array}$ & 3 & 3 & 2 & 66,66 & Cukup \\
\hline 12. & $\begin{array}{l}\text { Pelaksanaan refleksi berlangsung sesuai dengan susunan } \\
\text { acara yang direncanakan }\end{array}$ & 3 & 3 & 3 & 75,00 & Baik \\
\hline & Jumlah Skor & 36 & 36 & 35 & 81,66 & Baik \\
\hline
\end{tabular}

Hasil dari data pada Tabel 1 merupakan nilai angket guru model dalam pelaksanaan siklus I dengan menggunakan proses kegiatan lesson study pada tahap perencanaan (plan), pelaksanaan (do) dan refleksi (see) dengan nilai $81,66 \%$ dikatagorikan baik. Maka dapat disimpulkan bahwa guru model berhasil dalam melaksanakan pembelajaran untuk 
aplikasi lesson study, pada tahap siklus I tim observer dan guru model akan membahas dari kelebihan dan kekurangnya.

\section{Siklus II}

Pada tahap siklus II merupakan tahap refleksi dari siklus I tahapan proses pembelajaran sama melaksanakan pembelajaran lesson study dimana tim penelitian sebagai observer. Pada tahap ini tim melihat proses pembelajaran lesson study oleh guru model. Guru model melaksanakan pembelajaran lesson study dengan tahapan perencanaan (plan), dimana pada tahap ini guru model memperbaiki kekurangan dan perbaikan dari siklus I dari persiapan pembelajaran lesson study. Pada tahap pelaksanaan (do) guru model menerima dari kekurangan pembelajaran lesson study yang dilaksanakan pada siklus I serta memperbaiki dari kekurangan tersebut dan dilaksanakan pada siklus II. Sedangkan pada tahap kegiatan refleksi (see) guru model mengevaluasi hasil kegiatan pada siklus I, jika pelaksanaan ada kelemahan dan kekurang di tahap ini maka menjadi suatu acuan untuk diperbaiki serta sebagai pedoman untuk pembelajaran selanjutnya. Adapun hasil yang diperoleh dalam tahap siklus II yang didapat oleh guru model terdapat pada Taber 2 .

Tabel 2. Hasil Penelitian Siklus II Pelaksanaan Lesson Study

\begin{tabular}{|c|c|c|c|c|c|c|}
\hline No & Indikator & GM1 & GM2 & GM3 & $\%$ & Kriteria \\
\hline 1. & Perlengkapan perangkat pembelajaran & 4 & 4 & 3 & 91,67 & Sangat Baik \\
\hline 2. & $\begin{array}{l}\text { Kemampuan apersepsi yang akan dilaksanakan pada } \\
\text { saat membuka pelajaran }\end{array}$ & 4 & 3 & 3 & 83,33 & Baik \\
\hline 3. & Kejelasan dalam penyampaian materi & 3 & 3 & 3 & 75,00 & Baik \\
\hline 4. & $\begin{array}{l}\text { Guru model memanfaatkan model dan media } \\
\text { pembelajaran sesuai dengan perangkat pembelajaran } \\
\text { yang disebutkan dalam RPP }\end{array}$ & 3 & 3 & 3 & 75,00 & Baik \\
\hline 5. & $\begin{array}{l}\text { Guru model melaksanakan pembelajaran kepada } \\
\text { siswa belajar secara berkelompok dalam } \\
\text { pembelajaran }\end{array}$ & 4 & 3 & 3 & 83,33 & Baik \\
\hline 6. & Melakukan evaluasi pembelajaran & 3 & 3 & 3 & 75,00 & Baik \\
\hline 7. & $\begin{array}{l}\text { Melaksanakan pembelajaran dengan umpak balik } \\
\text { dan pujian }\end{array}$ & 4 & 3 & 3 & 83,33 & Baik \\
\hline 8. & Menyimpulkan materi pelajaran & 4 & 3 & 3 & 83,33 & Baik \\
\hline 9. & Kemampuan untuk menutup pembelajaran & 4 & 3 & 3 & 83,33 & Baik \\
\hline 10. & $\begin{array}{l}\text { Penggunaan waktu sesuai dengan rencana alokasi } \\
\text { waktu dalam RPP }\end{array}$ & 4 & 3 & 3 & 83,33 & Baik \\
\hline 11. & $\begin{array}{l}\text { Guru model yang mengajar dapat menerima saran } \\
\text { perbaikan }\end{array}$ & 4 & 3 & 3 & 83,33 & Baik \\
\hline 12. & $\begin{array}{l}\text { Pelaksanaan refleksi berlangsung sesuai dengan } \\
\text { susunan acara yang direncanakan }\end{array}$ & 4 & 3 & 3 & 83,33 & Baik \\
\hline & Jumlah Skor & 47 & 39 & 43 & 89,58 & Baik \\
\hline
\end{tabular}

Hasil dari data pada Tabel 2 merupakan hasil siklus II dengan menggunakan proses kegiatan lesson study pada tahap perencanaan (plan), pelaksanaan (do) dan refleksi (see) dengan nilai $89,58 \%$ dikatagorikan baik. Hasil dari siklus II merupakan hasil pembahasan tim observer dan guru model dari siklus I. Maka dapat disimpulkan bahwa guru model berhasil dalam merefleksi kekurangan dan kelemahan dari siklus I untuk dilanjutkan pada siklus II, pada tahap ini suasana belajar menjadi aktif dan kreatif sehingga siswa antusias untuk belajar.

Berdasarkan hasil penelitian di yang dilaksanakan pada siklus I dan siklus II dari tahapan pembelajaran lesson study oleh guru 
model. Maka hasil yang didapat dalam penelitian adalah bahwa kegiatan lesson study ini baik untuk diterapkan bagi guru model terhadap pelajaran biologi, dikarenakan pembelajaran lesson study dapat meningkatkan kompetensi profesional guru dalam aplikasikannya untuk proses belajar dan pembelajaran serta membuat siswa lebih aktif dan kreatif. Adapun hasil penelitian ini didukung oleh pendapat menurut Putri, et al. (2013) berdasarkan hasil penelitian yang menunjukkan adanya peningkatan dari siklus I ke Siklus II. pelaksanaan lesson study pembelajaran bahasa Indonesia di MTsN Lubuk Buaya Padang, pelaksanaan lesson study sudah sesuai dengan prosedur yang tetapkan dalam pembelajaran lesson study, yaitu plan (perencanaan), do (pelaksanaan) dan see (refleksi). Ketiga tahapan tersebut dapat meningkatkan kreativitas guru dan memotivasi siswa dalam belajar Bahasa Indonesia.

Berkenaan dengan pendapat hasil dari penelitian diatas maka menurut Nudji (2014) yang menyatakan bahwa lesson study dapat meningkatkan kemandirian belajar mahasiswa. Menurut Rozak \& Fauziah (2013) menyatakan Implementasi lesson study berdampak positif bagi pembinaan dan peningkatan kompetensi pedadogik guru bahasa Indonesia. Sedangkan menurut farida, A (2016) menyatakan melalui lesson study dosen matematika inilah diharapkan dapat meningkatkan kinerja dosen dan akhirnya berdampak pada kualitas pembelajaran dan mahasiswa.

Hasil penelitian atas juga sesuai dengan penelitian Subadi (2015) menyatakan bahwa peningkatan kualitas perkuliahan dapat dilakukan dengan lesson study. Selain itu sistem peningkatan pembelajaran aktif,inovatif, kreatif bagi mahasiswa dengan perkuliahan berbasis lesson study modifikasi. Sedangkan menurut pendapat dari Rokhmaniyah \&
Surandari (2016) dari hasil penelitian menyatakan bahwa peningkatan kualitas dari hasil penerapan lesson study dalam pengembangan bahan pembelajaran berbasis potensi lokal untuk meningkatkan kompetensi profesional guru SD di Kabupaten Kebumen tahun 2015 mencapai 90\% pembelajaran berbasis potensi lokal siswa menjadi lebih tertarik, senang, antusias, dan hasil belajarnya meningkat.

\section{KESIMPULAN}

Hasil penelitian menunjukkan bahwa pada siklus I dengan menggunakan proses kegiatan lesson study pada tahap perencanaan (plan), pelaksanaan (do) dan refleksi (see) dengan nilai $81,66 \%$ yang dikatagorikan baik. Hasil penelitian pada siklus II dengan menggunakan proses kegiatan lesson study pada tahap perencanaan (plan), pelaksanaan (do) dan refleksi (see) menunjukkan nilai $89,58 \%$ yang dikatagorikan baik.

\section{UCAPAN TERIMA KASIH}

Penyusunan jurnal penelitian ini tidak terlepas dari berbagai pihak yang mendukung baik dari segi moril dan materil. Oleh sebab itulah tim peneliti banyak mengucapkan terima kasih kepada LPPM \& PM Universitas Samudra yang telah mendanai penelitian dari dana DIPA UNSAM. Ucapan terima kasih juga kami sampaikan kepada kepala sekolah dan guru di Madrasah Aliyah Busthanul Ulum Kota Langsa.

\section{DAFTAR PUSTAKA}

Rozak, A., \& Fauziah, E. (2013). Implementasi lesson study sebagai upaya peningkatan kompetensi pedagogik guru bahasa indonesia di SMP kabupaten Cirebon. Jurnal Pendidikan Bahasa dan Sastra, 13(1), 1-11. 
Farida, A. (2016). Implementasi Lesson Study Untuk Meningkatkan Kinerja Dosen Matematika STMIK Duta Bangsa Surakarta. Jurnal Derivat, 3(2), 17-24.

Putri, I., Atmazaki, \& Syahrul, R. (2013) Pelaksanaan Lesson Study dalam Pembelajaran Bahasa Indonesia Siswa Kelas VII.5 MTsN Lubuk Buaya Padang. Jurnal Bahasa, Sastra dan Pembelajaran, 1(1): 109-117.

Lewis, C. 2002. Does Lesson study Have a Future in the United States? Nagoya Journal of Education and Human Development. 1, 1-23.

Nudji, D. A. (2014). Upaya Meningkatkan Kemandirian Belajar Mahasiswa PPKN Melalui Pembelajaran Lesson Study. Jurnal Heritage, 2(2), 9-18.

Padlurrahman, P., \& Novianti, B. A. (2013). Peningkatan Kompetensi Dosen Melalui Lesson Study pada Program Studi Pendidikan Fisika STKIP Hamzanwadi Selong. Educatio, 8(1), 81-94.

Rokhmaniyah, R., \& Surandari, K. C. (2016). Lesson Study Pengembangan Bahan Pembelajaran Berbasis Potensi Lokal untuk Meningkatkan Kompetensi Profesional Guru SD di Kabupaten Kebumen. Premiere Educandum: Jurnal Pendidikan Dasar dan Pembelajaran, 6(02), 162-173
Subadi, T. (2012). Peningkatan Profesional Dosen Melalui Program Perluasan Lesson Study Pada Jurusan IPS MIPA dan Biologi FKIP Universitas Muhammadiyah Surakarta. Publikasi Ilmiah UMS, 1-10

Subanji dan Isnandar (2010) Meningkatkan Profesionalisme Guru Sekolah Dasar Melalui Teachers Quality Improvmen Program (TEQIP) Berbasis Lesson Study, 1(1) (http://www.jurnaleducation.id), diakses tanggal 24 Maret 2010.

Susilo, H. (2006). Apa dan Mengapa Lesson Study Perlu Dilakukan untuk Meningkatkan Profesionalisme Guru dan Dosen MIPA. In Makalah. Disajikan dalam Seminar Peningkatan Profesionalisme Guru dan Dosen MIPA melalui Lesson Study, di Singaraja (Vol. 25).

Republik Indonesia. (2005). Undang-undang RI Nomor 14 Tahun 2005Tentang Guru dan Dosen. Lembaran Negara RI Tahun 2005, No. 14. Sekretariat Negara. Jakarta

White, A. L., \& Lim, C. S. (2008). Lesson study in Asia Pacific classrooms: Local responses to a global movement. ZDM, 40(6), 915-925 